\title{
Urgency of Project Based Learning Model in Social Studies Learning to Improve Students Learning Achievement
}

\section{Siti Samsiyah, Akhmad Arif Musadad, Musa Pelu}

Universitas Sebelas Maret

sitisamsiyah.ss82@gmail.com

\author{
Article History \\ accepted 1/09/2020
}

approved 4/10/2020

published 1/12/2020

\begin{abstract}
This study aims to describe the importance of a project based learning model in social studies learning to improve student achievement. This research is a descriptive qualitative study with a naturalistic approach. This research was conducted at SMP IT MTA Karanganyar. Data collection was carried out through in-depth interviews, observation and document analysis. The research instrument is the author himself as a data collector. The data validation was done by using triangulation techniques, double checking, and peer question and answer. Data analysis was performed using interactive analysis techniques which included data collection, data reduction, data display, and verification of conclusion. From the research results it can be concluded that the project based learning model is very important in social studies learning to improve student achievement. The increase in student learning achievement can be seen in the increase in student learning outcomes in material relics of the Hindu and Buddhist kingdoms in Indonesia. Project Based Learning assists teachers in developing student skills in making products that have benefits for students in participating in classroom learning. This condition is the main asset used in implementing the 2013 curriculum to create a generation that is superior, intelligent, creative, has quranic morals and environmentally friendly characters.
\end{abstract}

Keywords: Learning achievement, project based learning, social studies learning

\begin{abstract}
Abstrak
Penelitian ini bertujuan untuk mendeskripsikan pentingnya model project based learning dalam pembelajaran IPS untuk meningkatkan prestasi belajar siswa. Penelitian ini adalah penelitian kualitatif deskriptif dengan pendekatan naturalistik. Penelitian ini dilaksanakan di SMP IT MTA Karanganyar. Pengumpulan data dilakukan melalui wawancara mendalam, observasi dan analisis dokumen. Instrumen penelitian adalah penulis sendiri sebagai pengumpul data. Validasi data dilakukan dengan teknik trianggulasi, pengecekan ulang, dan Tanya jawab sejawat. Analisis data dilakukan dengan menggunakan teknik analisis interaktif yang meliputi pengumpulan data, reduksi data, tampilan data, dan verifikasi penarikan kesimpulan. Dari hasil penelitian dapat ditarik kesimpulan bahwa model project based learning sangat penting dalam pembelajaran IPS untuk meningkatkan prestasi belajar siswa. Peningkatan prestasi belajar siswa terlihat pada meningkatnya hasil belajar siswa pada materi peninggalan kerajaan Hindu dan Buddha di Indonesia. Project based learning membantu guru dalam mengembangkan keterampilan siswa dalam membuat produk yang memiliki manfaat bagi siswa dalam mengikuti pembelajaran di kelas. Kondisi ini merupakan modal utama yang digunakan dalam menerapkan kurikulum 2013 untuk mewujudkan generasi yang unggul, cerdas, kreatif, berakhlak qur'ani dan berwawasan lingkungan.
\end{abstract}

Kata kunci : Prestasi belajar, project based learning, pembelajaran IPS

Social, Humanities, and Education Studies (SHEs): Conference Series https://jurnal.uns.ac.id/shes

p-ISSN 2620-9284

e-ISSN 2620-9292

This work is licensed under a Creative Commons Attribution-ShareAlike 4.0 International License. 
SHEs: Conference Series 3 (2) (2020) 243- 251

\section{PENDAHULUAN}

Pendidikan merupakan upaya sadar yang diarahkan untuk mempersiapkan peserta didik melalui kegiatan pengajaran, bimbingan dan latihan bagi perannya di masa yang akan datang (Rohman, 2011: 10). Pendidikan juga memegang peranan yang penting dalam menumbuhkan generasi milineal yang handal sesuai dengan tujuan pendidikan yaitu untuk mengajarkan mereka mendokumentasikan pemikiran dengan benar dan dapat merefleksikan serta mengembangkan kreasinya. Pendidikan bertujuan membantu siswa dalam mengembangkan kecakapan dan karakteristik pribadinya ke arah yang positif (Sukmadinata dan Syaodih, 2012: 2).

Guna menunjang pendidikan pemerintah membentuk lembaga pendidikan yaitu sekolah. Di lingkungan sekolah, Guru memegang peran yang sangat strategis dalam setiap upaya untuk meningkatkan kualitas pendidikan (Akhmad Arif Musadad, 2014: 106). Oleh karena itu guru harus melakukan inovasi agar proses pembelajaran berjalan secara efektif. Sebagai pemberi informasi, guru harus dapat menciptakan, memimpin, merangsang dan menggerakkan siswa secara aktif dalam kegiatan belajar mengajar agar siswa bersemangat dan termotivasi untuk belajar. Salah satu mata pelajaran di SMP yang menunjang tercapainya tujuan pendidikan tersebut adalah IImu Pengetahuan Sosial (IPS).

Tujuan pembelajaran IPS adalah mewujudkan manusia yang dapat menggunakan segala kemampuan dan kreativitas diri peserta didik untuk menghadapi tantangan hidup. Kreativitas yang tinggi sangat dibutuhkan agar tujuan yang ditetapkan dalam Kompetensi Dasar bisa tercapai. Terasahnya kreativitas peserta didik mampu menunjang tercapainya hasil belajar. Kreativitas peserta didik dapat diperoleh berdasarkan pengalamannya, baik diluar sekolah maupun didalam lingkungan sekolah, untuk itu diharapkan pendidik dapat mengimplementasikan pembelajaran sesuai dengan tujuan kurikulum 2013. Kenyataan di lapangan menunjukkan, guru belum sepenuhnya memahami bagaimana menyampaikan materi IPS agar dapat dipahami oleh siswa dan bagaimana mengaitkan pengetahuan siswa dengan tantangan kehidupan seharihari. Pembelajaran IPS masih diberikan melalui pengalaman membaca atau mendengarkan ceramah guru, tanya jawab, dan penugasan. Guru menggunakan ketuntasan materi dan kurang mengoptimalkan aktivitas belajar siswa (Akhmad Arif M, dkk, 2017: 43). Siswa hanya menerima penjelasan dari guru dan kurang aktif dalam pembelajaran. Hal ini mengakibatkan pembelajaran IPS hanya terfokus pada kegiatan menghafal dan pemahaman siswa menjadi rendah akibatnya prestasi belajar siswa juga rendah.

Pembelajaran konvensional menjadi pilihan para pendidik karena mudah digunakan dan tidak memerlukan persiapan yang rumit. Pembelajaran ini kurang menarik bahkan menimbulkan kebosanan dan pada akhirnya memberikan hasil pembelajaran yang memprihatinkan. Hal ini terbukti, berdasarkan hasil ulangan harian di kelas VII SMPIT MTA Karanganyar diketahui terdapat nilai siswa yang belum mencapai Kriteria Ketuntasan Minimal (KKM) yaitu pada submateri "Peninggalan-peninggalan kerajaan Hindu-Buddha di Indonesia". Hal ini menunjukkan bahwa siswa kurang memahami submateri "Peninggalan-peninggalan kerajaan Hindu-Buddha di Indonesia". Bila siswa mengalami kegagalan dalam belajar itu bukan semata-mata kesalahan siswa, tetapi mungkin juga karena pemilihan model pembelajaran guru yang kurang sesuai dengan karakteristik materi, siswa dan tujuan pembelajaran yang akan dicapai. Pembelajaran IPS tidak cukup hanya dengan menggunakan model pembelajaran kreatif dan inovatif yang banyak dikembangkan seperti sekarang ini, namun diperlukan model pembelajaran yang benar-benar memberikan makna bagi siswa. Guru perlu memiliki keterampilan merancang model pembelajaran. Pemilihan dan penggunaan model pembelajaran perlu bervariasi agar kegiatan pembelajaran dapat merangsang partisipasi dan keaktifan siswa serta bermakna bagi siswa dalam membangun pengetahuannya. Pembelajaran IPS 
perlu ditunjang dengan media, sumber belajar yang tepat serta siswa dapat mengalami, melihat, dan mengamati segala sesuatu yang terjadi di lingkungannya. "Pembelajaran akan lebih baik, jika subjek belajar mengalami atau melakukannya" (Sardiman, 2010:20). Prestasi yang dicapai siswa setelah pembelajaran, menjadi tolok ukur keberhasilan pembelajaran.

Untuk mengatasi masalah dalam proses pembelajaran diatas, dibutuhkan sebuah metode pembelajaran alternatif yaitu metode yang dapat digunakan sebagai cara untuk menggali kreativitas dan keterampilan peserta didik. Metode pembelajaran yang dapat menonjolkan kreativitas peserta didik dan dapat meningkatkan prestasi belajar peserta didik yaitu pembelajaran berbasis proyek (Project Based learning). Dalam penelitian ini, peneliti akan membahas urgensi model project based learning dalam pembelajaran IPS untuk meningkatkan prestasi belajar siswa.

\section{Landasan Teori}

Prestasi belajar berasal dari kata "Prestasi" dan "Belajar". Prestasi adalah hasil yang dicapai anak setelah belajar baik berupa angka, huruf, serta tindakan hasil belajar yang dicapai (Indratmoko Pribadi, 2016: 41). Belajar adalah suatu aktivitas mental/psikis yang berlangsung dalam interaksi aktif dengan lingkungan yang menghasilkan perubahan-perubahan dalam pengetahuan, keterampilan, dan nilai sikap (Winkel, 1996: 53). Hamalik (2003: 52) menyatakan bahwa belajar adalah modifikasi untuk memperkuat tingkah laku melalui pengalaman dan latihan serta suatu proses perubahan tingkah laku individu melalui interaksi dengan lingkungannya. Berdasarkan pendapat di atas dapat disimpulkan bahwa belajar adalah suatu proses yang dilakukan individu untuk memperoleh beberapa perubahan tingkah laku yang relatif tetap sebagai suatu hasil latihan atau pengalaman dengan lingkungannya. Prestasi belajar adalah hasil yang dicapai seorang siswa setelah mengikuti pelajaran di sekolah sehingga terjadi perubahan dalam dirinya dengan melihat hasil penguasaan pengetahuan dan keterampilan yang dikembangkan oleh guru setelah mengikuti asessment atau penilaian dan evaluasi. Penilaian dan evaluasi digunakan untuk mengukur prestasi belajar siswa yang merupakan tujuan dari pembelajaran.

Project Based Learning (PjBL) adalah model pembelajaran dengan pendekatan kontekstual yang lebih menekankan pada kegiatan-kegiatan kompleks, yaitu melakukan investigasi pemecahan masalah, melakukan kegiatan mandiri yang bermakna, dan mengkonstruksi pengetahuan sehingga menghasilkan produk nyata (Thomas dalam Wena, 2011: 145). Hal ini sejalan dengan Permendikbud No. 103 Tahun 2014, pembelajaran berbasis proyek (PjBL) adalah pembelajaran yang menekankan aktivitasaktivitas menghasilkan produk dengan menerapkan keterampilan meneliti, menganalisis, membuat, sampai dengan mempresentasikan produk nyata. Produk yang dimaksud dapat berupa desain, skema, karya tulis, karya seni, karya teknologi/prakarya. Proyek dapat dilakukan secara mandiri maupun kelompok berdasarkan permasalahan yang komplek. Project Based Learning (PjBL) bertujuan untuk memantapkan pengetahuan yang dimiliki siswa serta memungkinkan mereka memperluas wawasan pengetahuan mata pelajaran tertentu. PjBL memiliki potensi untuk memungkinkan siswa meneliti, merencanakan, merancang, dan merefleksikan penciptaan proyek teknologi yang berupa produk siswa (Doppelt, 2000).

Berdasarkan Permendiknas Nomor 22 Tahun 2006 IPS merupakan mata pelajaran wajib ditempuh peserta didik yang disusun secara sistematis, komprehensif, dan terpadu dalam proses pembelajaran menuju kedewasaan dan keberhasilan dalam kehidupan di masyarakat. Melalui IPS diharapkan peserta didik memperoleh pemahaman yang lebih luas dan mendalam pada bidang ilmu yang berkaitan. IPS mengkaji seperangkat peristiwa, fakta, konsep, dan generalisasi yang berkaitan dengan isu sosial. 
Fokus kajian IPS berupa berbagai aktivitas manusia dalam berbagai dimensi kehidupan sosial sesuai dengan karakteristik manusia sebagai makhluk sosial. Pada jenjang SMP/MTs mata pelajaran IPS memuat materi Geografi, Sejarah, Sosiologi, dan Ekonomi. Melalui mata pelajaran IPS peserta didik diarahkan untuk dapat menjadi warga negara Indonesia yang demokratis, dan bertanggung jawab serta warga dunia yang cinta damai. Di masa yang akan datang peserta didik akan menghadapi tantangan berat karena kehidupan masyarakat global selalu mengalami perubahan setiap saat. Oleh karena itu mata pelajaran IPS dirancang untuk mengembangkan pengetahuan, pemahaman, dan kemampuan analisis terhadap kondisi sosial masyarakat dalam memasuki kehidupan bermasyarakat yang dinamis (Permendiknas No. 22 Tahun 2006).

Berdasarkan teori di atas pembelajaran IPS bertujuan untuk mengembangkan kemampuan siswa dalam menghayati masa sekarang dengan dibekali pengetahuan masa lampau agar dapat mengambil pelajaran dan mengkaitkan masa lampau dengan masa kini dan yang akan datang. Siswa dapat belajar bagaimana menghargai dan melestarikan peninggalan-peninggalan sejarah yang ada disekitar tempat tinggalnya.

\section{METODE}

Penelitian ini adalah penelitian kualitatif deskriptif dengan pendekatan naturalistik. Penelitian dilaksanakan di SMP IT MTA Karanganyar yang beralamat di Jalan Lawu Harjosari RT 03 RW 02 desa Popongan, kecamatan Karanganyar. Subyek penelitian terdiri guru IPS dan siswa kelas VII. Penelitian ini menggunakan pendekatan naturalistik, oleh karena itu subyek penelitian dipilih dengan menggunakan teknik purposive sampling yang dapat memberikan informasi tentang pentingnya model project based learning dalam pembelajaran IPS untuk meningkatkan prestasi belajar siswa.

Pengumpulan data dilakukan melalui wawancara mendalam, observasi dan analisis dokumen. Wawancara mendalam dilakukan dengan guru IPS dan siswa kelas VII. Proses wawancara dilakukan dengan prosedur informal yang bebas dan pertanyaan non terstruktur tetapi berfokus pada masalah. Untuk menghindari bias data, penulis menggunakan perekam. Pengamatan dilakukan penulis dengan berpartisipasi langsung dalam pembelajaran dengan model project based learing dalam pembelajaran IPS pada materi peninggalan kerajaan Hindu-Buddha di Indonesia KD 3.4 Memahami berpikir kronologi, perubahan dan kesinambungan dalam kehidupan bangsa Indonesia pada aspek politik, sosial, budaya, geografis, dan pendidikan sejak masa praaksara sampai masa Hindu-Budha dan Islam.

Analisis data dilakukan dengan menggunakan teknik analisis interaktif yang meliputi pengumpulan data, reduksi data, tampilan data, dan verifikasi penarikan kesimpulan terhadap dokumen/arsip terkait model pembelajaran yang dilakukan. Instrument penelitian adalah penulis sendiri yang bertindak sebagai pengumpul data dari hasil belajar siswa. Validasi data dilakukan dengan teknik trianggulasi, pengecekan ulang, dan Tanya jawab sejawat (Moleong, 2007: 324). Trianggulasi dilakukan dengan mengecek ulang data yang dikumpulkan dari banyak sumber data, dengan menguji data hasil wawancara dan angket. Teknik Tanya sejawat dilakukan dengan mendiskusikan hasil penelitian dengan guru IPS, sehinga data yang diperoleh benarbenar valid.

\section{HASIL DAN PEMBAHASAN}

Hasil penelitian menunjukkan bahwa model project based learning sangat penting diterapkan dalam pembelajaran IPS untuk meningkatkan prestasi belajar siswa, terutama pada materi peninggalan kerajaan Hindu-Buddha di Indonesia. Penyesuaian 
SHEs: Conference Series 3 (2) (2020) 243- 251

materi tersebut tidak terlepas dari KD yang digunakan yaitu KD 3.4 Memahami berpikir kronologi, perubahan dan kesinambungan dalam kehidupan bangsa Indonesia pada aspek politik, sosial, budaya, geografis, dan pendidikan sejak masa praaksara sampai masa Hindu-Buddha dan Islam. Model project based learning membantu guru dalam mengembangkan keterampilan siswa membuat produk yang memiliki manfaat bagi siswa dalam mengikuti pembelajaran di luar kelas terhadap peninggalan-peninggalan kerajaan Hindu-Buddha di Indonesia. Melalui kegiatan ini siswa menjadi sadar untuk melestarikan warisan budaya bangsa sehingga memperkuat kepribadian bangsa (Musa Pelu dan Isawati, 2019: 397). Meningkatnya kesadaran siswa terhadap budaya bangsa sangat berkaitan dengan meningkatnya prestasi belajar siswa.

Project based learning ( $\mathrm{PjBL}$ ) berperan penting dalam mendorong siswa untuk bekerja dalam tim (Barak \& Maymon, 1998; Denton, 1994). Dengan cara ini, siswa menggabungkan kegiatan "langsung" dengan apa yang disebut Papert (1980) sebagai kegiatan "langsung". PjBL dapat digunakan sebagai alat untuk mengembangkan kompetensi siswa dengan bekerja pada proyek terintegrasi (Barlex, 2002). PjBL dapat menanamkan pemikiran kreatif dalam pembelajaran dan tidak hanya membutuhkan perubahan metode pengajaran dan lingkungan belajar, tetapi juga dalam penilaian produk. Produk siswa mencerminkan apa yang telah dipelajari siswa, bagaimana mereka mempertanyakan, menganalisis, mensintesis, memecahkan masalah, dan menciptakan ide-ide baru, dan bagaimana kemudian merancang dan membangun produk atau sistem yang bermanfaat. Produk juga menunjukkan bagaimana siswa berinteraksi secara intelektual, emosional, dan sosial dengan orang lain (Collins, 1991; Wolf, 1989). Sebuah proyek otentik berhubungan nyata dengan situasi kehidupan yang bersifat integratif. Salah satu elemen kunci untuk sukses dalam PjBL adalah melibatkan siswa dalam proses penilaian dan sebagai hasil akhir adalah meningkatnya prestasi belajar siswa.

Barak dan Doppelt (1999) telah menunjukkan bahwa dengan PjBL siswa mampu mengatasi masalah yang kompleks, mengembangkan solusi yang bergantung pada kreativitas, mendukung gagasan dengan menerapkan pemikiran lateral dan vertikal. Halhal yang harus diperhatikan dalam pembelajaran model project based learning adalah pemikiran kreatif yang dapat membantu pendidik berjuang untuk mengembangkan keterampilan berpikir tingkat tinggi secara bertahap di dua bidang utama. Yang pertama adalah pilihan topik proyek yang dibuat siswa. Ini termasuk dimensi kompleksitas, orisinalitas, dan kreativitas di satu sisi dan tingkat pemikiran matematika, logis, dan ilmiah di sisi lain. Area kedua mempertimbangkan proses berpikir dan belajar yang diterapkan ketika siswa mengembangkan proyek mereka dan mencakup pemecahan masalah, kerja Tim, dan pemikiran reflektif. Dengan demikian, belajar melalui perancangan dan implementasi proyek-proyek berdasarkan penilaian produk dan diarahkan pada pengembangan sistematis pemikiran vertikal dan lateral dapat mempromosikan pengajaran dan pembelajaran yang membantu keberhasilan integrasi siswa ke dalam dunia yang dinamis dan berubah di luar sekolah.

Model project based learning merupakan model pembelajaran yang menggunakan proyek (produk) sebagai inti pembelajaran. Dalam setiap kegiatan yang dilakukan siswa mendapatkan pengalaman secara langsung sehingga menemukan konsep-konsep baru, pengalaman baru, meningkatkan kreatifitas, dan meningkatkan prestasi belajar siswa. Guru berperan sebagai fasilitator dan menugaskan siswa untuk menyelesaikan produknya. Sementara siswa dapat belajar langsung bentuk dan model bangunan candi Sukuh yang kemudian mereka menghasilkan produk miniatur candi sukuh sebagai media dalam pembelajaran selanjutnya.

Model project based learning berperan dalam meningkatkan prestasi belajar siswa, mengingat sulitnya membuat produk miniatur candi Sukuh dapat menambah pengetahuan dan pemahaman siswa bahwa jaman dulu lebih sulit dibandingkan sekarang. Sehingga siswa bangkit dan timbul kesadaran sejarahnya untuk menghargai 
SHEs: Conference Series 3 (2) (2020) 243- 251

dan melestarikan peninggalan sejarah. Meningkatnya kesadaran sejarah siswa seiring dengan meningkatnya prestasi belajar siswa. Model project based learning (PjBL) adalah model pembelajaran yang melibatkan keaktifan peserta didik dalam memecahkan masalah, baik secara individu maupun kelompok.

Pentingnya model project based learning dalam pembelajaran IPS dapat dilihat dari lima kelebihan PjBL menurut Moursound dalam Wena (2011: 147) yaitu: (1) Meningkatkan motivasi belajar siswa, (2) Meningkatkan kecakapan siswa dalam pemecahan masalah, (3) Meningkatkan keterampilan memperoleh informasi melalui sumber-sumber informasi, (4) Meningkatkan semangat dan keterampilan berkolaborasi/bekerjasama, (5) Meningkatkan keterampilan dalam manajemen sumber daya, sehingga meningkatkan kemampuan kognitif siswa, kemampuan afektif, dan nilai siswa sehingga meningkat pula prestasi belajar siswa. Menurut Darmadi (2017: 127) kelebihan model PjBL yaitu: (1) Meningkatkan motivasi belajar pesrta didik untuk belajar, mendorong kemampuan mereka untuk melakukan pekerjaan penting dan mereka perlu untuk dihargai; (2) Meningkatkan kemampuan pemecahan masalah; (3) Membuat pesrta didik menjadi lebih aktif dan berhasil memecahkan problemproblem yang kompleks; (4) Meningkatkan kolaborasi; (5) Mendorong peserta didik untuk mengembangkan dan mempraktikan keterampilan komunikasi; (6) Meningkatkan keterampilan peserta didik dalam mengelola sumber (7) Memberikan pengalaman kepada peserta didik pembelajaran dan praktik dalam mengorganisasi project dan membuat alokasi waktu dan sumber-sumber lain seperti perlengkapan untuk menyeesaikan tugas; (8) Menyediakan pengalaman belajar yang melibatkan peserta didik secara kompleks dan dirancang untuk berkembang sesuai dunia nyata; (9) Melibatkan para peserta didik untuk belajar mengambil informasi dan menunjukan pengetahuan yang dimiliki, kemudian diimplementasikan dengan dunia nyata; (10) Membuat suasana belajar menjadi menyenangkan, sehingga peserta didik maupun peserta didik maupun pendidik menikmati proses pembelajaran.

Dapat disimpulkan bahwa model pembelajaran PjBL siswa merencanakan sebuah proyek tentang suatu hal, mereka menjadi sangat terlibat di dalamnya. Dan, ketika mereka menyelesaikan proyeknya dengan baik, maka siswa memperoleh kepuasan. Hal ini jauh lebih memotivasi daripada pemberian reward dari guru, walaupun tentunya ini terjadi secara simultan. Motivasi intrinsik sangat penting. Dalam teorinya, ketika siswa memperoleh kepuasan karena suatu kesuksesan, maka motivasi mereka untuk belajar dalam kegiatan berikutnya juga akan lebih baik. Hal ini didukung oleh hasil penelitian yang dilakukan oleh Made dkk (2014) yang menggunakan model pembelajaran berbasis proyek (Projcet Based Learning), memperlihatkan bahwa terdapat perbedaan peningkatan hasil belajar siswa yang belajar dengan model pembelajaran berbasis proyek dan pembelajaran konvensional.

Hasil belajar IPS siswa menggunakan model pembelajaran project based learning $(\mathrm{PjBL})$ menunjukkan rata-rata hasil belajar peserta didik meningkat lebih besar dibandingkan dengan menggunakan model ceramah. Hal ini terbukti bahwa pembelajaran berbasis proyek (Project Based Learning) dapat meningkatkan hasil belajar siswa serta kemampuan bekerja sama siswa, karena siswa diberikan kesempatan untuk mengembangkan ide dan belajar untuk mencari solusi dari masalah nyata. Sebagaimana dikatakan oleh Abidin (2016:167-168), bahwa model pembelajaran ini sangat baik digunakan untuk mengembangkan motivasi belajar, meningkatkan kemampuan memecahkan masalah dan membiasakan siswa mendayagunakan kemampuan berpikir tinggi. Model pembelajaran berbasis proyek sebagai sebuah model pembelajaran yang berfungsi sebagai tulang punggung pengembangan pengalaman siswa dalam belajar dan guru dalam mengajar. Model pembelajaran Project Based Learning merupakan model pembelajaran yang berfokus pada konsep-konsep dan prinsip-prinsip utama (central) dari suatu disiplin, melibatkan siswa dalam kegiatan pemecahan masalah dan tugas-tugas bermakna lainnya, memberi peluang siswa 
bekerja secara otonom mengkonstruk belajar mereka sendiri, dan puncaknya menghasilkan produk karya siswa bernilai, dan realistik (BIE, dalam Ngalimun, 2016:185). Submateri "Peninggalan-peninggalan kerajaan Hindu-Buddha di Indonesia" perlu disampaikan dengan cara yang tepat agar konsep yang ada benar-benar tertanam sehingga siswa memahami materi. Dengan menggunakan model pembelajaran Project Based Learning, siswa dapat memahami konsep materi dengan baik dan dapat mengembangkan pola pikirnya dalam membuat suatu proyek yang dapat menghasilkan sebuah produk yang dapat digunakan dalam kehidupan.

\section{SIMPULAN}

Berdasarkan hasil penelitian tersebut maka dapat disimpulkan bahwa model project based learning sangat penting dalam pembelajaran IPS untuk meningkatkan prestasi belajar siswa terutama materi peninggalan kerajaan Hindu-Buddha di Indonesia pada umumnya dan kabupaten karanganyar pada khususnya. Peningkatan kesadaran sejarah siswa terlihat pada penerapan nilai historis dan edukatif candi Sukuh dalam kehidupan sehari-hari, seperti potensi diri, etos kerja, pengendalian diri, toleransi, terbuka, dan ketuhanan yang maha esa. Model pembelajaran PjBL merupakan merupakan model pembelajaran yang menggunakan proyek (kegiatan) sebagai inti pembelajaran. Model PjBL merupakan salah satu pembelajaran yang bermakna melibatkan secara aktif, memfasilitasi kemampuan berfikir kreatif serta dapat menciptakan pembelajaran yang menyenangkan. Melalui PjBL siswa dilatih untuk menyelesaikan masalah, mengambil keputusan, melakukan investigasi dan membuat suatu karya untuk membantu mengatasi masalah.

Berdasarkan penelitian yang telah dilakukan, maka disarankan kepada guru dan calon guru untuk memperhatikan hal-hal sebagai berikut: (1) model pembelajaran berbasis proyek dapat dijadikan salah satu alternatif model pembelajaran yang digunakan dalam pembelajaran IImu Pengetahuan Sosial (IPS); (2) Manajemen waktu yang baik dalam penerapan setiap model khususnya pembelajaran berbasis proyek akan memberikan dampak yang positif terhadap hasil belajar yang ingin dicapai; dan (3) perumusan masalah dan langkah kerja proyek harus diinformasikan kepada siswa secara jelas dan terarah, agar siswa dapat menjalani proses pembelajaran dengan baik.

\section{DAFTAR PUSTAKA}

Abidin, Yunus. (2016). Desain Pembelajaran Dalam Konteks Kurikulum 2013 Bandung: PT. Refika Aditama.

Akhmad Arif Musadad. 2014. The Preliminary Study and Analysis on the Need of Teachers for Social Science Training with Multicultural Insight. American International Journal of Social Science Vol.3 No.5 Oktober.

Barak, M. \& Doppelt, Y. (1999). Mengintegrasikan program CoRT untuk kreatif berpikir ke dalam kurikulum teknologi berbasis proyek. Penelitian dalam Pendidikan Sains dan Teknologi, 17 (2), 39-151.

Barak, M., \& Maymon, T. (1998). Aspek kerja Tim diamati dalam tugas teknologi di sekolah menengah pertama. Jurnal Pendidikan Teknologi, 9 (2), 3-17.

Barlex, D. (2002, Maret). Hubungan antara sains dan desain dan teknologi dalam kurikulum sekolah menengah di Inggris. Dalam I. Mottier \& M. J. De Vries (Eds.), Prosiding Konferensi PATT12 (hlm. 3-12). 
Collins, A. (1991). Portofolio untuk penilaian guru biologi. Jurnal Sekolah Evaluasi Personil dalam Pendidikan, 5, 147-167.

Darmadi. (2017). Pengembangan Model dan Metode Pembelajaran dalam Dinamika Belajar Siswa. Yogyakarta: CV BUDI UTAMA.

Denton, H. (1994). Peran Kerja Kelompok / Tim dalam Desain dan Teknologi: Beberapa Kemungkinan dan Masalah. Di F. Banks. (Ed.), Teknologi Pengajaran (hal. 145150). London: Routledge.

Doppelt, Y. \& Barak, M. (2002). Murid mengidentifikasi aspek-aspek kunci dan hasil dari lingkungan pembelajaran teknologi, Jurnal Studi Teknologi, 28 (1), 12-18.

Doppelt, Y. (2000, Juni). Mengembangkan kompetensi siswa melalui pemikiran kreatif dalam proyek teknologi. Makalah disajikan pada Konferensi Israel ke-28 tentang Teknik Mesin, Universitas Ben-Gurion di Negev, Beer-Sheva, Israel.

Hamalik, Oemar. (2003). Proses Belajar Mengajar. Jakarta: UI Press.

Indratmoko Pribadi. (2016). Penerapan Model Pembelajaran Kooperative Tipe Jigsaw dengan Media Visualisasi Proklamasi Kemerdekaan Indonesia untuk Meningkatkan Kesadaran Sejarah dan Prestasi Belajar Siswa Kelas XI IPS 2 SMAN 6 Surakarta. Thesis. Surakarta: UNS.

Moleong, L.J. (2007). Metodologi Penelitian Kualitatif. Bandung: Remaja Rosdakarya.

Musa Pelu \& Isawati. (2019). Historical Value of Cetho Temple as Local Culture-Based Character Education Source and Material. Advances in Social Science, Education and Humanities Research (ASSEHR) Volume 279.

Ngalimun. (2016). Strategi dan Model Pembelajaran Edisi Revisi. Yogyakarta: Aswaja Pressido.

Papert, S. (1980). Mindstorms, Anak-Anak, Komputer dan Ide-Ide Kuat. New York: Buku Dasar.

Permendikbud No.103 tahun 2014. (2016). Model-model Pembelajaran. Jakarta: Kementerian pendidikan dan kebudayaan Direktorat Pendidikan Dasar dan Menengah Direktorat Pendidikan SMP.

Permendiknas No. 22 Tahun 2006. Standar Isi. Jakarta: Kementerian pendidikan dan kebudayaan Direktorat Pendidikan Dasar dan Menengah Direktorat Pendidikan SMP.

Rohman, A (2011). Memahami Pendidikan dan Ilmu Pendidikan. Yogyakarta: CV. Aswaja Pressindo.

Rosdiana, Djono, dan Akhmad Arif Musadad. (2017). Pengaruh penggunaan Model pembelajaran Problem based learning, inquiri dan konvensional terhadap prestasi belajar sejarah ditinjau dari minat belajar siswa (studi eksperimental kelas XI SMA Negeri Se-Kabupaten Bima Tahun Pelajaran 2015/2016. Historika, Vol.20 No.1 Tahun 2017.

Sardiman. (2010). Interaksi dan Motivasi Belajar Mengajar. Jakarta: Rajawali Pers. 
Sukmadinata, N. Sy. \& Syaodih, E. (2012). Kurikulum dan Pembelajaran Kompetensi. Bandung: Refika Aditama.

Wena, M. (2011). Strategi Pembelajaran Inovatif Kontemporer: Suatu Tinjauan Konseptual Operasional. Jakarta: PT Bumi Aksara.

Winkel, W.S. (1996). Psikologi Pengajaran. Yogyakarta: Universitas Sanata Darma.

Wolf, D. (1989). Penilaian portofolio: Pekerjaan sampel murid. Pendidikan Kepemimpinan, 45 (4), 35-39. 